\title{
REVIEW
}

\section{From Neural Stem Cells to Myelinating Oligodendrocytes}

\author{
Bernard Rogister, ${ }^{*}$ Tamir Ben-Hur, ${ }^{\dagger}$ and Monique Dubois-Dalcq ${ }^{\ddagger}$ \\ *Department of Human Physiology, University of Liège, Liège, Belgium; ${ }^{+}$Department of \\ Neurology, Hadassah Medical School, Jerusalem, Israel; and $¥$ Unite de Neurovirologie et \\ Régénération du Système Nerveux, Institut Pasteur, Paris, France
}

\begin{abstract}
The potential to generate oligodendrocytes progenitors (OP) from neural stem cells (NSCs) exists throughout the developing CNS. Yet, in the embryonic spinal cord, the oligodendrocyte phenotype is induced by sonic hedgehog in a restricted anterior region. In addition, neuregulins are emerging as potent regulators of early and late OP development. The ability to isolate and grow NSCs as well as glial-restricted progenitors has revealed that FGF2 and thyroid hormone favor an oligodendrocyte fate. Analysis of genetically modified mice showed that PDGF controls the migration and production of oligodendrocytes in vivo. Interplay between mitogens, thyroid hormone, and neurotransmitters may maintain the undifferentiated stage or result in OP growth arrest. Notch signaling by axons inhibits oligodendrocyte differentiation until neuronal signals-linked to electrical activity - trigger initiation of myelination. To repair myelin in adult CNS, multipotential neural precursors, rather than slowly cycling OP, appear the cells of choice to rapidly generate myelin-forming cells.
\end{abstract}

\section{INTRODUCTION}

Myelination is an essential feature of vertebrate evolution. It provides a selective advantage because myelinated axons can propagate nerve impulses very fast through the complex nervous system circuitry of vertebrates without taking more space (Stoffel and Bosio, 1997). Another important role of myelin is to support axonal function and integrity (Griffith et al., 1998; Yin et al., 1998). In most mammals, myelination takes place during late embryonic and early postnatal life. Schwann cells, which make peripheral nerve myelin, develop from neural crest stem cells (NCSC), whereas oligodendrocytes, which make central nervous system (CNS) myelin, are derived from multipotential neural stem cells (NSC). These myelinforming cells emerge several days (even weeks in man) before they start to myelinate. Studies over the past decade have elucidated how Schwann cells develop from NCSC (Stemple and Anderson, 1992; reviewed by Jessen and Mirsky, 1998). How multipotential NSC give rise to oligodendrocytes has began to unravel recently and will be discussed in this review.

There is a wealth of information on the properties of progenitor cells destined to become oligodendrocytes, called oligodendrocyte progenitors (OP) or O-2A (reviewed by Raff, 1989). These cells can be isolated from optic nerve as well as from other regions of the developing CNS. The presence of specific antigens on their surface has allowed OP purification, clonal analysis, and characterization of their growth and differentiation properties (reviewed by Dubois-Dalcq and Armstrong, 1992; Pfeiffer et al., 1993; McMorris and McKinnon, 1996). OP are bipolar and migratory cells that express specific gangliosides, the chondroitin-sulfate proteoglycan NG2, and the platelet-derived growth factor receptor alpha (PDGF$\mathrm{R} \alpha$ ) (Nishiyama et al., 1996). This receptor signals OP mitosis and migration in response to PDGF derived from neurons and astrocytes (Raff, 1989; Sasahara et al., 1992). Basic fibroblast growth factor (FGF2) is also a mitogenic and chemoattractant ligand for OP (Milner et al., 1996; Simpson and Amstrong, 1999). The differential regulation of FGF receptors 1,2, and 3 observed during progression toward oligodendrocyte differentiation has been correlated with the diversity of responses to this ligand (Bansal et al., 1996). FGF2 upregulates PDGF-R $\alpha$ expression in OP and blocks their differentiation into oligodendrocytes (McKinnon et al., 1990; Bogler et al., 1990). Similarly, an isoform of neuregulin (NRG), glial growth factor 2 (GGF2), stimulates mitosis of passaged OP and delays differentiation of neonatal and adult CNS OP (Canoll et al., 1996; Shi et al., 1998).

As OP mature, they become multipolar, synthesize 


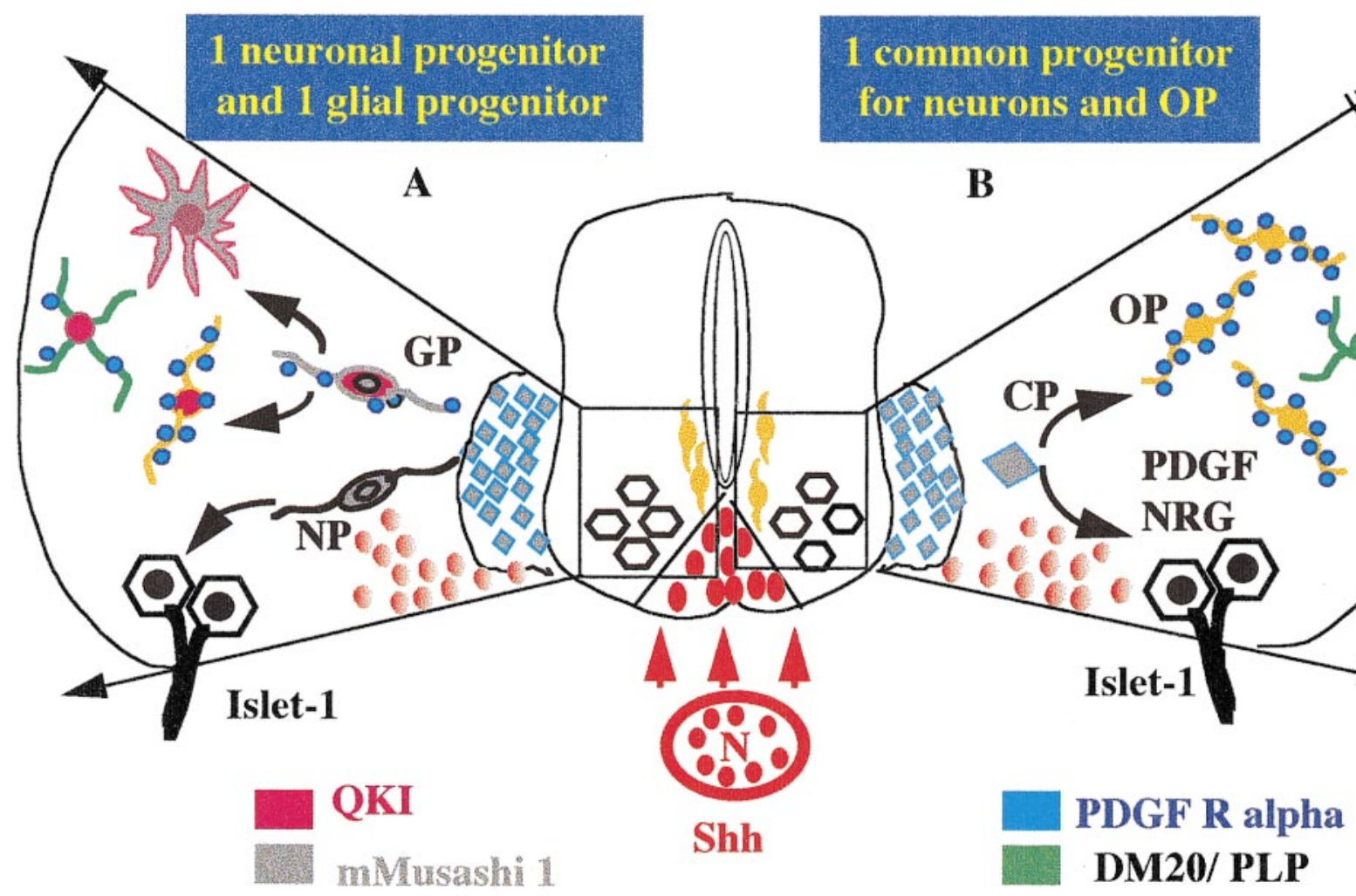

FIG. 1. Oligodendrocyte emergence in the embryonic spinal cord. In the center of the scheme, Shh (red dots) secreted by the notochord (N) induces its own expression in the floor plate. Shh graded signaling then induces motoneurons which express Islet-1 (black) and OP on each side of the ventral ventricular zone (ochrous). Two hypotheses on the lineage origins of oligodendrocyte are depicted in the close up (see text for details and references). (A) Neuronal and glial precursors emerge from different subdomains of the germinative zone (grey diamonds). Neuronal precursors (NP) express the RNA-binding protein mMusashi 1 (gray), but not QKI-5 (garnet), while glial precursors (GP) express both proteins. GP and OP (positive for PDGF-R $\alpha$ in blue dots) continue to express QKI-5 until they become PLP+ oligodendrocytes (green). Note that mMusashi 1 is down regulated in the oligodendrocyte lineage while its expression persists (together with QKI-5) in astrocytes (stellate cell, grey and garnet). (B) A common precursor (CP) migrating out of the germinative zone (large grey diamonds) generates motoneurons (black) and OP expressing PDGF-R $\alpha$ (ochrous with blue dots). Motoneurons, which differentiate first, synthesize PDGF as well as NRG. PDGF-R $\alpha$ is down regulated when PLP+ oligodendrocytes differentiate (green).

sulfatides, and glycolipids recognized by the $\mathrm{O} 4$ antibody, divide more slowly, and are less motile, probably because PDGF-R $\alpha$ is down regulated (reviewed by McMorris and McKinnon, 1996). Postmitotic differentiated oligodendrocytes make galactocerebroside, a major glycolipid of myelin, and need IGF-1 receptor signaling to survive (Barres et al., 1992). Both transcriptional and postranscriptional controls lead to high level of myelin gene expression when the multiple processes of oligodendrocytes enwrap axons (Hudson et al., 1996).

\section{THE ORIGIN OF OLIGODENDROCYTES: SONIC HEDGEHOG AND OTHER SIGNALS}

Where do OP first appear? As myelination starts in the embryonic spinal cord, it is not surprising that OP are first detected in this CNS region (reviewed by Miller, 1996; Richardson et al., 1997). In chick and rodent spinal cord, they emerge on each side of the ventral germinative zone around the ependymal canal just above the floor plate. This site of emergence is conserved from birds to man, where OP are first detected in the anterior spinal cord at 45 days postconception (Hajihosseini et al., 1996). In rodents, OP detected in this region express sulfatides, the PDGF-R $\alpha$, as well as some myelin genes at E14 (Fig. 1). It is striking that differentiation of oligodendrocytes occurs in such restricted foci at that time in spite of the widespread neuroectoderm distribution of precursors able to generate myelin-forming cells (Hardy and Friedrich, 1996). Signals leading to the organization of the ventral region of the spinal cord come from the notochord, a midline transient embryonic structure (Dodd et al., 1998). Grafting a second notochord close to the dorsolateral part of the chick 
neural tube induces a second floor plate in this region. This floor plate then induces the formation of ectopic groups of motoneurons and oligodendrocytes. Accordingly, no motoneurons and oligodendrocytes develop in mutant mice that lack a notochord and floor plate in the caudal region of the spinal cord. The notochord secretes the protein sonic hedgehog (Shh) whose graded signaling mediates differentiation of floor plate and motoneurons in the anterior spinal cord (reviewed in Edlund and Jessell, 1999) (Fig. 1). Shh binds to Patched, a putative 12-transmembrane domain receptor whose expression in the neural tube is triggered by Shh (Marigo and Tabin, 1996). In chick spinal cord explants, the motoneuron and oligodendrocyte phenotypes can be induced by a recombinant aminoterminal fragment of Shh at the same range of concentrations (Richardson et al., 1997). Antibodies that neutralize Shh in vivo can prevent the emergence of OP in the chick spinal cord (Orentas et al., 1999). Shh does not appear to stimulate OP proliferation in spinal cord explants. Once OP have been generated and express the PDGF-R $\alpha$, they can respond to neuronalderived PDGF by mitosis and migration toward the lateral regions of the spinal cord where they differentiate in myelinating oligodendrocytes (Fig. 1).

As motoneurons arise in the rodent ventral spinal cord about 2 days before oligodendrocytes, factors derived from differentiating neurons may influence the time of oligodendrocyte emergence (Miller, 1996). Such factor(s) may be encoded by the NRG1 gene since E10 spinal cord explants of NRG1 ${ }^{-} /^{-}$mice show neurite outgrowth but do not generate OP (Vartanian et al., 1999). This defect can be corrected by addition of GGF-2, a type II NRG isoform (ibidem). It is presently unclear whether OP emergence in vivo is regulated by this type II NRG isoform or another neuronal isoform. A Type III isoform-which has a different aminoterminus than GGF2-is indeed highly expressed in anterior horn neurons at the time of OP emergence (Meyer et al., 1998). One possibility is that NRG derived from motoneurons acts on OP after their induction by Shh. As ErbB4 is expressed in the ventral region of embryonic spinal cord (ibidem), this receptor could mediate NRG signaling of newly born oligodendrocytes.

There is much interest in identifying the sites of origin of oligodendrocytes in the diencephalic and telencephalic regions. In chick, the ventral midline region under the third ventricle, above the optic chiasma, gives rise to OP migrating into optic nerves (Ono et al., 1997). Similarly, the ventral diencephalon contains PDGF-R $\alpha$-expressing cells that may migrate to the corners of the lateral ventricles and eventually populate the hemispheres (Richardson et al., 1997). As Shh is expressed in the ventral diencephalic and telencephalic region where the medial ganglionic eminence is located (Rubinstein et al., 1998), this morphogen could play a role in oligodendrocyte emergence from these regions. Consistent with this is the observation that NSCs from the ganglionic eminence produce several orders of magnitude more oligodendrocytes than cortical NSCs from E13 rats (Birling and Price, 1998). Moreover, experiments with chick-quail chimeras showed that cells originating from the ganglionic eminence can generate numerous OP that migrate in the forming white matter (Martinez and Combos, 1998). Shh expression was recently described in retinal ganglion cells and the protein present in developing optic nerve axons may stimulate astrocyte proliferation (Wallace and Raff, 1999). Similarly, Shh is made by Purkinje cells in the cerebellum where it acts as a mitogen for granule cell precursors (Wechsler-Reya and Scott, 1999). Future studies should determine in which cell types Shh and Patched are expressed in the midbrain and/or drain hemispheres whether graded signaling by Shh takes place there as it does in the spinal cord.

\section{THE QUESTION OF THE LINEAGE ORIGIN OF OLIGODENDROCYTES}

What is the lineage origin of the first oligodendrocyte precursors in different regions of the CNS? Studies on embryonic spinal cord have led to two different models. In the first model, motoneurons and oligodendrocytes would have a common precursor that would be specified by Shh (Richardson et al., 1997) (Fig. 1B). In this scenario, OP would be generated after motor neurons but not in response to factors coming from the newly generated neurons (Sun et al., 1998). Oligodendrocytes can indeed develop normally in spinal cord explants of mutants lacking motoneurons (ibidem). The second model proposes that neuronal and glial precursors are already distinct from each other in the ventricular zone (VZ) because they emerge from different subdomains (Hardy, 1998) (Fig. 1A). In favor of this hypothesis is the expression of Quaking-5 (QKI-5) RNA binding protein isoform in proliferative precursors within a VZ subdomain of the ventral spinal cord (Fig. 1A). Precursors migrating from the VZ continue to synthesize QKI-5 transcript and coexpress the PDGF-R $\alpha$. These glial precursors generate QKI-5-positive astrocytes and oligodendrocytes (Hardy, 1998) (Fig. 1A). In contrast, QKI-5 is down-regulated, while another RNA-binding protein mMusashi is upregulated in neuronal precursors apparently arising from another VZ region (Sakakibira and Okano, 1997).

A third model based on studies of OP emergence in rhombencephalic and diencephalic regions proposes that oligodendrocytes may have more than one precur- 
sor origin. The initial observation was that transcripts encoding the major protein of CNS myelin, proteolipid protein (DM20/PLP), are expressed as early as E9.5 in mouse spinal cord, diencephalon, hypothalamus, and rhombencephalon (Timsit et al., 1995). Studies in transgenic mice expressing the LacZ gene under the control of the PLP promoter revealed that the PLP gene is turned on in neural precursors within the midbrain neuroepithelium. These multipotential precursors may give rise to oligodendrocytes, which maintain DM20/ PLP expression, while downregulation of PLP would take place in other cell types (Spassky et al., 1998). Intriguingly, PLP-Lac Z-positive cells often do not coincide with those expressing PDGF-R $\alpha$ and do not respond to PDGF by mitosis (ibidem). DM20/PLP + cells detected in the VZ before birth can divide (Spassky et al., 1998) but their physiological mitogen has not been identified yet. The evolutionary and biological implications of a single or dual origin of oligodendrocytes will be discussed elsewhere (Spassky et al., submitted).

\section{HOW DO NEURAL STEM CELLS (NSC) RESTRICT THEIR POTENTIAL TO A MOSTLY GLIAL FATE?}

NCSs initially divide symmetrically in the neuroepithelium, whereas asymmetric division takes place later to allow some daughter cells to continue to self renew while others differentiate (Huttner and Brand, 1997). Such asymmetric division may be controlled by the Notch pathway, which signals cell fate specification in flies. Some cells in the neuroepithelium express Notch1 asymmetrically at their basal pole and, after horizontal division, only the basal daughter cell inherits Notch1 expression and becomes a migrating neuron (Chenn and McConnell, 1995; Fig. 2). OP also express Notch1 (Wang et al., 1998a), but it is not known if this receptor is expressed in glial precursors emerging from the germinative zone. The CNS precursors that emanate from the early and late neuroepithelium (or VZ) have a different fate in the rodent brain. From E10 to E15-16, NSCs in the VZ mostly generate neurons. Starting E17-18 and throughout the postnatal period, NSCs in the subventricular zone (SVZ) essentially generate glia (Fig. 2). One exception to this switch of the germinative zone from neuronogenesis to gliogenesis is the anterior SVZ, which gives rise to olfactory neuron progenitors throughout life (Wichterle et al., 1997).

Progressive restriction in cell fate in the developing nervous system is initially specified by extrinsic factors and later by intrinsic signaling (reviewed by Edlund and Jessell, 1999). Early VZ NSCs proliferate in response to FGF2 and give rise to neurons, astrocytes and oligodendrocytes (Davis and Temple, 1994; Weiss, 1996). Such multipotential NSCs can be isolated from brain throughout life and express nestin which is down regulated when the cells differentiate (Weiss et al., 1996; McKay, 1997). A single factor can strongly influence the number of committed CNS progenitors arising from NSCs in vitro and differences in these progenitor populations will determine their responses to environmental cues (reviewed by McKay, 1997; Lillien, 1998) (Fig. 2). PDGF can instruct NSCs to become neurons whereas high FGF2 concentrations or a brief treatment with thyroid hormone induce more oligodendrocytes to form

FIG. 2. Factors controlling NSC proliferation and their progressive restriction toward a glial/oligodendrocyte fate. The scenario proposed here is based on in vitro and in vivo studies in rodents. Progression in time is horizontal (not to scale) and differentiation is vertical. Growth stimulation by mitogens (green letters) is represented by the red circled arrow. Factors inducing differentiation are written in blue. Some surface molecules expressed by precursor cells are in brown. After mitosis, NSCs leaving the ventricular zone (VZ) express Notch. NSCs in the VZ respond to FGF2 and generate mainly migrating neurons. At E15/16, NSCs become responsive to EGF. Gliogenesis from the subventricular zone (SVZ) starts at E17/18. PSA-NCAM+ glial precursor mitosis is triggered by NSC mitogens as well as PDGF which is also the major mitogen for OP. BMP2/4 and CNTF induce an astrocyte fate, whereas thyroid hormone (T3) enhances the growth/survival of glial precursors and later favors oligodendrocyte differentiation. OP in the adult CNS cycle more slowly (larger red circled arrow) than neonatal OP and can reverse to the neonatal phenotype in response to a cocktail of PDGF + FGF2 or PDGF + GGF2 (see text for details and references).

FIG. 3. Transition from dividing OP to postmitotic, myelinating oligodendrocytes. While dividing in response to PDGF, OP (ochrous) progressively accumulate cyclin-dependent kinase inhibitors (Cdk) p27 and p21. T3 and neuronal-derived glutamate can limit/block the number of mitogen-driven divisions of OP, while these Cdk inhibitors accumulate, leading to cell cycle exit. Other mitogens such as GGF2 and FGF2 can maintain proliferation of multipolar OP (reacting with the O4 antibody, green). Turquoise arrows indicate the effect of soluble factors: IGF-1 enhances survival of neurons/axons and postmitotic oligodendrocytes; both IGF-1 and T3 increase myelin gene expression in myelinating oligodendrocytes (blue). Notch (pink) is present on the surface of OP interacting with axons expressing Jagged (dark blue dots), a Notch ligand that inhibits oligodendrocyte differentiation. When Jagged is down-regulated, oligodendrocytes start to enwrap axons. At the premyelinating stage, axons have scattered $\mathrm{Na}+$ channels in their membrane (red dots). Oligodendrocytes then secrete a factor causing clustering of these channels at the sites of the future nodes of Ranvier. On the right is a cartoon of an oligodendrocyte synthesizing several myelin internodes (modified from Colman et al., 1996). See text for details and references. 
2
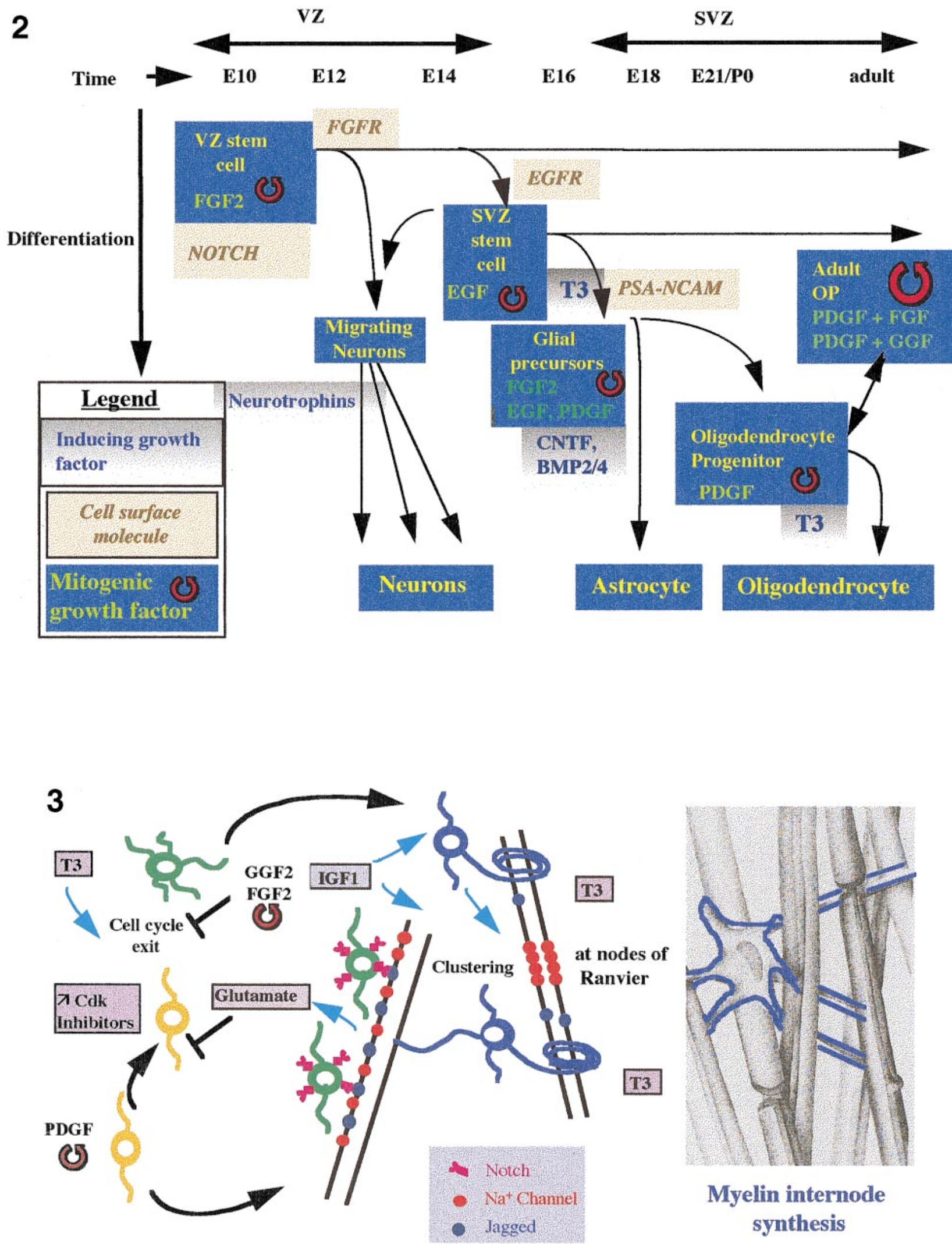
at the expense of neurons (Williams et al., 1997; Qian et al., 1997; Johe et al., 1996). Similarly, FGF2 and T3 favor an oligodendrocyte over a neuronal fate in neonatal NSCs grown in spheres (Ben Hur et al., 1998). Astrocyte differentiation can be induced by bone morphogenetic proteins (BMP2/4) or ciliary neurotrophic factor (CNTF) in vitro (Gross et al., 1996; Rajan and McKay, 1998). EGF-responsive precursors are generated from FGFresponsive NSCs in vitro and in SVZ during late embryonic life (Ciccolini and Svendsen, 1998). Increasing EGF receptor density in NSCs at this stage will enhance the probability to generate astrocytes (Burrows et al., 1997).

How these growth factors precisely control cell fate and orchestrate oligodendrocyte generation in vivo is not clearly understood. Several relevant factors are expressed at the appropriate time in the developing brain: PDGF and its receptor are detected in E14 brain (Reddy and Pleasure, 1992; Sasahara et al., 1992), FGF2 expression increases from E15 to E18 before gliogenesis occurs (Giordano et al., 1992) and BMPs are detected in SVZ during gliogenesis. The density of receptors on NSCs can dictate their sensitivity to certain extrinsic clues (reviewed by Edlund and Jessell, 1999). For instance, increasing the density of EGF receptors by gene transfer in NSCs at E16 in vivo induces an astrocyte phenotype in these NSCs progeny (Lillien, 1998). To gain more insight into the way NSCs sense a changing microenvironment, one could follow by two photon microscopy how migrating precursors become restricted in their fate in intact tissues. The ability to express green fluorescent proteins with different spectrum of emission and color under the control of promoters turned on at different stages of oligodendrocyte development allows exploration of these processes. Transgenic mice and transfection studies have already demonstrated that this approach permits isolation of stage-specific CNS precursors and to characterize their receptor make up and response to growth factors (Chandross et al., 1999; Wang et al., 1998b).

\section{GLIAL-RESTRICTED PRECURSORS}

In Drosophila nervous system, the glia cell missing (GCM) gene regulates the neuron/glia fate choice and its overexpression can turn neurons in glia (Jones et al., 1995; Bernardoni et al., 1998). Two mouse homologues of GCM have been isolated and one of them, GCM1, is expressed in astrocytes and OP but not in differentiated oligodendrocytes (Nait-Oumesmar and Lazzarini, 1999). These studies suggest a role for GCM1 in specification of glial cell fate in mammals.
Glial-restricted precursors have been derived from NSCs isolated from E10.5 spinal cord and cultured in FGF2 (Rao and Mayer-Proschel, 1997). These cells, which are immunolabeled by the A2B5 antibody, arose in clones that also contained neurons. When these A2B5 cells were immunopanned and cloned in the presence of FGF2/PDGF and, subsequently, in PDGF alone, they generated oligodendrocytes and astrocytes (ibidem). Retroviral marking studies have shown that the postnatal SVZ generates mostly glial precursors that migrate in white matter and cortex, giving rise to oligodendrocytes and astrocytes in vivo (Levison and Goldman, 1993; Williams and Price, 1995). Such bipotential glial precursors have been isolated from neonatal rat brain cultures by immunoselection using antibodies to the embryonic polysialylated form of neural cell adhesion molecule (PSA-NCAM) (Ben-Hur et al., 1998). These precursors grow into clusters in response to FGF2, PDGF, or EGF and, after adhesion, generate mostly OP, oligodendrocytes, and astrocytes, but rarely neurons (Fig. 2). Thus expression of PSA-NCAM on these precursors coincides with restriction to a glial fate. Yet, PSA-NCAM+ precursors located in cortex can still generate neurons in addition to oligodendrocytes and astrocytes in vitro (Marmur et al., 1998).

PSA-NCAM has been associated with neurite growth, cell migration, and/or progression along a particular CNS lineage (Rougon et al., 1993). PSA-NCAM is present on progenitor cells migrating toward the olfactory bulb and on neural precursor cells migrating out of neurospheres in vitro (Hu et al., 1996; Murray and Dubois-Dalcq, 1997). The PSA homopolymer of $\alpha-2,8$ sialic acid moieties with high negative charge density and antiadhesive properties may provide binding sites for growth factors and increase their concentration. Alternatively, it could modulate signals transmitted via growth factor receptors (Kiss and Rougon, 1997). Thus the PSA moiety on NCAM could enhance cell signaling by FGF and/or PDGF, which influence growth and migration of glial precursors in the white matter. In this way, it could play a role in the passage from multipotentiality to a more restricted fate, while the migrating cell is sensing new microenvironments, in particular, axonal signals.

\section{THYROID HORMONE INFLUENCES SEVERAL STAGES OF OLIGODENDROCYTE DEVELOPMENT}

Hypothyroidism can cause hypomyelination in animal and man (Walters and Morell, 1981) and there is 
mounting evidence that thyroid hormone can act on the oligodendrocyte lineage from its early stage till myelination. T3, the active form of this hormone, is first detected at E17 in the fetal rat brain. When thyroid hormone deficiency is induced by ganciclovir treatment in late embryos of transgenic mice expressing the thymidine kinase gene in thyroid cells, oligodendrocyte development is affected before differentiation starts (Ahlgren et al., 1997). This correlates with the inductive effects of T3 on oligodendrocyte development from NSCs in vitro.

There are two thyroid hormone receptors (THR) genes ( $\alpha$ and $\beta$ ), each generating two isoforms (alpha 1 and 2 and beta 1 and 2) by alternative splicing and these receptors are part of the nuclear receptor family (reviewed by Hudson et al., 1996). THR $\alpha$ isoforms are expressed early in brain development. In PSA-NCAM+ neural precursors, T3 increases the mitogenic and survival response to FGF2 (Ben-Hur et al., 1998) (Fig. 2). THR $\beta 2$ is expressed on these PSA-NCAM neural precursors and OP before being down regulated during differentiation (Barres et al., 1994). THR $\beta 1$ expression increases at the time when T3 triggers cell cycle exit in vitro and active myelination occurs in vivo (Barres et al., 1994; Carre et al., 1998) (Figs. 2 and 3). This is in keeping with the observation that THR $\beta$ dimers induce the transcription of the myelin basic protein (MBP), whereas heterodimers of THR $\beta$ and the peroxisome proliferatoractivated receptor (PPAR) — which is expressed in early OP-activate transcription of the PLP gene (Tosic et al., 1992; Hudson et al., 1996; Granneman et al., 1998). As PPAR also activates a key enzyme in long chain fatty acid metabolism, nuclear receptors may help coordinate myelin lipid and protein synthesis in oligodendrocytes (Hudson et al., 1996).

Thus, developmental regulation of distinct isoforms of THR may be the key to the multiple ways that this hormone acts on the oligodendrocyte lineage. To further investigate this question, oligodendrocyte development should be investigated in double mutants in THR $\alpha$ and $-\beta$ (Gauthier et al., 1999). In addition to thyroid hormone, other hormones binding to nuclear receptors such as estrogens and progesterone may also influence oligodendrocyte development.

\section{CONTROL OF OLIGODENDROCYTE GROWTH IN THE DEVELOPING AND ADULT CNS}

Once OP have been generated by glial precursors, extrinsic and intrinsic factors control their growth and progression toward oligodendrocyte differentiation while the dialogue with axons is starting. One essential extrinsic signal is PDGF-AA, which is a major mitogen for rodent OP in vivo (Figs. 1 and 2). There are indeed much fewer OP expressing PDGF-Ralpha in the spinal cord and cerebellum of PDGF-A ${ }^{-/-}$mice while their number is normal in PDGF-B ${ }^{-1-}$ mice (Fruttiger et al., 1999). Since these mice do not make PDGFAA, there is a substantial amount of oligodendrocyte death and hypomyelination. Conversely, in transgenic mice overexpressing PDGF-A in neurons, OP divide more than normally. This results in a large increase in OP, which eventually populate not only the white matter but also the grey matter of the spinal cord (Calver et al., 1998). These supernumerous oligodendrocytes are later eliminated by programmed cell death, so that the number of oligodendrocytes becomes normal in adult transgenic mice. Oligodendrocyte cell numbers are also enhanced by survival factors such as IGF-1 (Barres et al., 1992; Raff et al., 1993) (Fig. 3). However, in IGF-1 knock out mice, the key factor decreasing oligodendrocyte number is the loss of neurons in hypomyelinated regions (Cheng et al., 1998). Thus IGF-1 acts as a positive regulator, enhancing survival and differentiation of both neurons and oligodendrocytes. Together these studies indicate that axonal signals adjust oligodendrocyte numbers according to neuron/axon numbers to obtain a full set of myelin internodes.

Among intrinsic factors that may control OP development, three types of transcription factors (TF) are expressed at the time when precursors proliferate and become committed to an oligodendrocyte fate (reviewed by Hudson, 1999). One zinc-finger DNAbinding protein, MyT1, cloned on the basis of its binding affinity for a sequence within the PLP promoter, is expressed in OP but also in developing neurons (Armstrong et al., 1995; Kim et al., 1997). It is intriguing that a xenopus homolog of MyT1, X-MyT1, promotes commitment to a neuronal fate by conferring insensitivity to Notch signaling (Bellefroid et al., 1996). As Notch signaling can inhibit OP differentiation (Wang et al., 1998a), MyT1 expression may be required to overcome this inhibition in the rodent oligodendrocyte lineage. Several POU-domain TFs, Oct 6 (also called Tst-1/SCIP) and Brn-1/Brn-2, are also expressed by OP (Schreiber et al., 1997) together with Sox DNA-binding proteins 10 and 11 (Kuhlbrodt et al., 1998). The latter proteinswhich are homologous to the sex determining factor SRY-may modulate the regulation of glial-specific genes by POU-domain proteins (ibidem). When the POU-domain Oct6 is overexpressed at late stage of oligodendrocyte development, myelin assembly is im- 
paired, indicating that oligodendrocytes are very sensitive to dysregulation of this TF (Jensen et al., 1998).

OP from optic nerve tend to divide a set number of times before withdrawing from the cell cycle and differentiating into oligodendrocytes (reviewed by Raff, 1989; Barres et al., 1994) (Fig. 3). If two daughters cells are isolated and cultivated clonally, they go through the same number of cell cycles before differentiating. This has lead to the proposal that a "biological clock" counts cell cycles before allowing oligodendrocyte differentiation. A clue of what the molecular basis of the clock might be came from studies of the cyclin-dependent kinase (Cdk) inhibitors p27Kip1 or p27. Cdks are essential to the phosphorylation of target proteins during the mitotic cycle and their inhibition will eventually lead to cell cycle arrest which is required for oligodendrocyte differentiation. p27 accumulates in dividing OP at each cell cycle (Durand et al., 1997). When PDGF is omitted from culture medium, p27 intracellular concentration increases even more while oligodendrocytes differentiate (reviewed by Edlund and Jessel, 1999). Accordingly, OP generated from transgenic $\mathrm{p} 27^{-/-}$mice go through more cell cycles in response to PDGF before differentiating and are more responsive to PDGF by mitosis (Casaccia-Bonnefil et al., 1997; Durand et al., 1998). As T3 regulates timing of cell cycle exit (see above), one would predict that this hormone would trigger an increase in these Cdk inhibitors. A p27 increase is indeed observed in neuroblastoma cells overexpressing THR $\beta 1$ after treatment with T3, which causes cell cycle arrest and differentiation (Perez-Juste and Aranda, 1999). Both p27 and another Cdk inhibitor p21 ${ }^{\mathrm{CIP} 1}$ accumulate in OP whose proliferation has been blocked by glutamate, or by activation of $\beta$-adrenergic receptors with norepinephrine or selective agonists (Ghiani et al., 1999a) (Fig. 3). Similarly p27 and p21 are also increased by depolarization of OP membrane (Ghiani et al., 1999b). However, glutamate or depolarization-induced increase of p27 in OP may cause cell cycle arrest without leading to differentiation. Therefore, we are left with the question, what sets the differentiation program into motion?

If an appropriate number of oligodendrocytes were generated only once in a lifetime, CNS remyelination might not be possible or minimal. Yet, in most vertebrates, there is evidence that remyelination is an efficient repair mechanism in the CNS (reviewed by DuboisDalcq and Armstrong, 1990). This suggests the existence of a pool of precursor cells in the adult CNS. Consistent with this idea is the observation that OP do not always differentiate synchronously in vitro. Single OP isolated from optic nerve can generate large clones where oligodendrocytes coexist with a population of slowly divid- ing OP. These only differentiate when high levels of insulin-which bind to the IGF-1 receptor-or neurons are present (Dubois-Dalcq, 1987). A progressive increase in OP cell cycle time takes place from birth to adult. The cell cycle of OP isolated from the adult CNS is 3- to 4-times longer and their migration speed is slower than those of neonatal OP (reviewed by Noble et al., 1992) (Fig. 2). These slowly cycling "adult" OP can transform into rapidly proliferating cells ressembling neonatal OP after exposure to PDGF and FGF2 or to PDGF and GGF2 when the intracellular cAMP concentration is raised (Shi et al., 1998). GGF2, however, blocks their differentiation as it does in neonatal OP (Figs. 2 and 3).

The Notch signaling pathway may play a role in the maintainance of a pool of unmyelinating OP as Jagged1, a Notch ligand, inhibits oligodendrocyte differentiation (Wang et al., 1998a). As Jagged1 is expressed by differentiated oligodendrocytes, it could signal Notch1 on OP, resulting in the persistence of these cells in the adult CNS (Shi et al., 1998; reviewed by Blaschuk and ffrenchConstant, 1998). If GGF2 and Jagged1 act this way in vivo, other signals are needed to overcome this differentiation inhibition and induce remyelination.

\section{CROSSTALK BETWEEN NEURONS AND OLIGODENDROCYTES AND THE INITIATION OF MYELINATION}

Molecular interactions between oligodendrocytes and axons go through a series of stages whose exact sequence needs to be established (Fig. 3). In particular, the molecular signals imparted by electrical activity should be identified as such activity appears essential to CNS myelination and probably also to remyelination (Demerens et al., 1996). When electrical activity is suppressed by the sodium channel blocker tetrodotoxin, myelination is inhibited in vitro and in vivo (ibidem). Accordingly, if cells are maintained in a depolarized state, myelination is not initiated. Electrical activity may control the release of factors like PDGF, which is produced by neurons and enhances OP mitosis and survival (Barres and Raff, 1993). Myelin-forming cells also send essential signals to axons. The normal expression of myelin genes such as myelin-associated glycoprotein (MAG) and PLP appears necessary for axonal function and survival throughout life (Griffiths et al., 1998; Yin et al., 1998). Connexin 32 is highly expressed in premyelinating oligodendrocytes (Scherrer et al., 1995). As there is no function known yet for this gap junction protein, could it play a role in the cross-talk with axons? How oligodendrocytes signal axons is an important 
field of investigation as axonal structure and function are often altered in demyelinating diseases such as multiple sclerosis (Trapp et al., 1998).

At the premyelinating stage, optic nerve oligodendrocytes secrete a protein that causes clustering of $\mathrm{Na}^{+}$ channels along retinal ganglionic cell axons and these clusters appear at the predicted intervals needed between myelin internodes (Kaplan et al., 1997). Mice deficient in galactosyl-transferase have abnormalities of the node and paranode structure (Dupree et al., 1998). This suggests that galactocerebrosides and sulfatides are essential to the normal formation of nodes of Ranvier and that these glycolipids mediate interactions between the myelinating cell and the axon.

Another player in the early axon/oligodendrocyte crosstalk is Jagged, a ligand that signals Notch1 receptors on OP. When migrating OP come into contact with axons, Jagged 1 on the axonal membrane may signal Notch1 on OP and inhibit oligodendrocyte differentiation (Wang et al., 1998a). Only when Jagged1 is downregulated along axons will OP start to enwrap axons and differentiate (Fig. 3). In this scenario, Notch receptor activation would not control cell identities/fate but rather, it would regulate the time and site of oligodendrocyte generation (ibidem). But how is Jagged down regulated on axons and then turned on in differentiated oligodendrocytes? Is this an example where the Notch-mediated cell communication switches its signaling mode from one cell to its neighbor (Artavanis-Tsakonas et al., 1999)?

There is increasing evidence that cells of the oligodendrocyte lineage are well equipped to respond to a variety of neurotransmitters. The discovery that $\mathrm{OP}$ bear functional delayed-rectifying $\mathrm{K}^{+}$channels in their membrane and express non-NMDA Kainate and AMPApreferring glutamate receptors raises the possibility of their essential role in the axon/glia cross talk (Gallo et al., 1996). Glutamate released by axons of glutamatergic neurons could be a regulator of OP numbers as it can inhibit OP proliferation in vitro and in cerebellar tissue slices (Fig. 3) (Knutson et al., 1997; Yuan et al., 1998). This biological effect is caused, at least in part, by an increase in intracellular $\mathrm{Na}^{+}$concentration and a subsequent block of OP $\mathrm{K}^{+}$channels. PDGF and FGF2 can act in concert to increase glutamate receptor subunit expression (Chew et al., 1997). Glutamate agonists, in turn, can modulate the phosphorylation of OP nuclear transcription factors such as CREB through a MAP-kinase-dependent signal transduction pathway (Pende et al., 1997).

Glutamate may not be the only neurotransmitter that regulates OP proliferation and differentiation as these cells also express adrenergic receptors as well as functional receptors to acetylcholine, serotonine, glycine, and GABA (Belachew et al., 1998a). Interestingly, glycine receptors on OP display pharmacological properties distinct from those observed in neurons (Belachew et al., 1998b). The analysis of mice deficient in glutamate and glycine receptors subunits may elucidate how these receptors function in the oligodendrocyte lineage. The regulation of oligodendrocyte function by neurotransmitters and electrical activity may well result from a three-partner crosstalk because astrocytes release neurotransmitters in response to a rise of intracellular calcium concentration triggered by neurons (reviewed by Araque et al., 1999).

The molecular signal(s) that initiate CNS myelination are still a mystery. In the PNS, NRGs are distributed along the axonal membrane of dorsal root ganglia (DRG) neurons and can activate the TF Krox 20, which is essential for myelin formation by Schwann cells (Murphy et al., 1996; Vartanian et al., 1997). As DRG axons are also myelinated by oligodendrocytes in the spinal cord dorsal columns, axonal signals of CNS myelination may be similar. Interestingly, OP in culture express another member of the Krox family, Krox 24, whose downregulation coincides with upregulation of myelin basic protein (MBP) (Sock et al., 1997). As cells of the oligodendrocyte lineage express NRG receptors ErbB2 and 4, secreted and/or transmembrane NRG isoforms on axons could lead to phosphorylation of these receptors (Vartanian et al., 1997). Would this signal result in the turn on of myelin genes at an early stage of myelination? Yet, there are other candidates for this function such as adhesion molecules. MAG, a member of the family of sialoadhesins (called siglecs), is on myelinating processes that interact directly with axons (Filbin, 1996). Neurons and their processes have binding sites for MAG and an engineered MAG Fc molecule immunoprecipitates as 190-kDa sialoglycoprotein present on axons (De Bellard and Filbin, 1999). Thus MAG could initiate a transduction cascade at the axon interface. Studies in knock out mice indicate that MAG plays a role in the formation of the spiraling loops, the number of myelin loops, and the maintenance of myelin (Martini and Schachner, 1997; Li et al., 1998). Finally, the recent finding of compartmentation of NCAM 120 and F3 adhesion molecules with activated Fyn kinase in oligodendrocytes suggests a new mode of signaling cascades involved in the initiation of myelination (Krämer et al, 1999).

Extracellular matrix (ECM) molecules may also turn out to play a role in the initiation of myelination. These proteins bind to integrins, which are made of two transmembrane glycoprotein subunits ( $\alpha$ and $\beta$ ). There is a large number of these subunits forming many different heterodimeric receptors that can link ECM molecules to cytoskeleton elements. During oligodendro- 
cyte development, there is a sequential expression of $\alpha v \beta 1$ integrin, which is involved in OP migration, followed by $\alpha v \beta 3$ and $\alpha v \beta 5$ during differentiation (Milner et al., 1996, 1997). While tenascin-C inhibits oligodendrocyte precursor migration (Kiernan et al., 1996), tenascin- $R$ has been shown to control oligodendrocyte differentiation in an autocrine manner (Pesheva et al., 1997). Vitronectin-which is expressed in the developing white matter-is a ligand for all $\alpha \mathrm{v}$ integrins on oligodendrocytes (discussed by Milner et al., 1997) and may therefore provide the necessary signal for migration and other functions mediated by these integrins. Laminin II (formerly called merosin) is also present in white matter tracts and in some CNS neurons (Powell et al., 1998). This ligand promotes oligodendrocyte sheath formation, an effect that appears mediated by the $\alpha 6 \beta 1$ integrin, suggesting a role for laminin II-integrin interactions in myelination (Buttery and ffrench-Constant, 1999).

To our knowledge, no master gene has been discovered that sets the myelination program into motion. Rather, several TFs expressed by OP and/or oligodendrocytes may control the myelination process by binding to specific sequences in myelin gene promoters, acting in cooperation or as dimers in the case of nuclear receptors (reviewed by Hudson, 1999). For example, the homeodomain protein Gtx is expressed only in myelinating oligodendrocytes and binds to specific sequences in the PLP and MBP genes (Awatramani et al., 1997). How the myelination program is precisely orchestrated remains to be elucidated.

\section{UNANSWERED QUESTIONS AND PERSPECTIVES}

We have discussed here how multipotential neural precursors in the germinative zone give rise to migratory cells that will generate glial-restricted precursors and/or OP destined to become oligodendrocytes. Many questions remain to be elucidated on the molecular mechanisms underlying these processes. How is induction of the oligodendrocyte phenotype by Shh in the embryonic spinal cord coordinated with the formation of neurons close to the ventral midline? Oligodendrocytes emerge above the $\mathrm{V} 3$ region where progenitors of visceral motoneurons are specified by the homeobox TF Nkx 2.2 in response to Shh (Briscoe et al., 1999). Is there a different TF factor specifying oligodendrocytes close to this $\mathrm{V} 3$ region? When a strong Shh signal is present, are oligodendrocytes rapidly specified without going through the glial-restricted stage? How do NRGs influence this process? What is the strength of graded Shh signalling in mid and basal forebrain and does it regulate emergence of all OP that will myelinate telencephalic white matter regions? Or are there other inducing factors at play in the brain?

Much remains to be elucidated about the regional specialization of the CNS germinative zone throughout life. Is the SVZ organized in domains that generate glial-restricted precursors destined to different regions of the postnatal rodent brain, just like the anterior VZ will generate neuronal progenitors destined to the olfactory bulb? Can cells transiently concentrate growth factors on their surface while they move? Is migration of OP initially mediated by gradients of chemotactic factors or chemokines (Robinson et al., 1998) and later by axonal signals? Does the regulation of cell surface receptors control several of these developmental processes, as appears to be the case with thyroid hormone, FGF, EGF, and PDGF receptors? Are there specific TFs involved in the migratory and mitotic activities of glial-restricted precursors and OP?

Unravelling NSC plasticity has implications for CNS myelin regeneration (reviewed by Brüstle and DuboisDalcq, 1999). The signals that drive NSC migration and fate are very conserved between species as human neural precursors engrafted in embryonic rat brain at the time of gliogenesis often become oligodendrocytes (Brüstle et al., 1998). Multipotential NSCs persist in adult CNS but it is only recently that their exact identity has started to be unravelled (reviewed by Barres, 1999). The surprise is that a new role for glia has been discovered (ibidem). SVZ astrocytes in one study (Doetsch et al., 1999) and ependymal cells in another (Johansson et al., 1999) were shown to become NSCs growing in neurospheres that could generate neuronal progenitors, astrocytes, and OPs. NSCs from adult CNS grown in neurospheres (whatever their origin!) can generate $\mathrm{OP}$, which myelinate myelin-deficient animals after transplantation (Zhang et al., 1999). Similarly, the fate of multipotential stem cells is shifted toward the oligodendrocyte phenotype when NSC are transplanted by intraventricular injection into the brain of dysmyelinated shiverer newborn mice (Yandawa et al., 1999). Moreover, a significant number of these transplanted mice showed decreased tremor and improvement of clinical phenotype because the grafted NSCs had migrated in many different regions of the CNS (ibidem). Glial-restricted PSA-NCAM+ precursors isolated from the neonatal rat brain can show an enhanced potential when transplanted into a focal demyelinated lesion in adult rat spinal cord (Keirstead et al., 1999). In this case, these precursors generate oligodendrocytes, astrocytes, and Schwann cells in vivo. Would these precursors also 
be able to generate neurons when grafted in regions where neurons have been destroyed? Or would OP present in adult CNS ever become multipotential (Barres, 1999)? This and other questions raised above open exciting prospects for investigators interested in the generation and regeneration of myelin-forming cells.

\section{ACKNOWLEDGMENTS}

We are grateful to Vittorio Gallo, Lynn Hudson, Boris Zalc, Charles ffrench-Constant, Brahim Nait-Oumesmar, Robert Lazzarini, and Jacqueline Trotter for helpful discussion/suggestions for this review and for sharing recent data with us. We thank Pierre LePrince, Roberto Bruzzone, Heinz Arnheiter, Isabelle Franceschini, and Viviane Calaora for critical reading of this review: Bernard Rogister is a senior Research Associate of the Belgian National Fund for Scientific Research. T. Ben-Hur is funded by the Israel Ministry of health chief scientist and a joint grant of the Hadassah and Hebrew University Medical School. M. Dubois-Dalcq is a grantee of the Multiple Sclerosis Society of Great Britain and Northern Ireland.

\section{REFERENCES}

Ahlgren, S. C., Wallace, H., Bishop, J., Neophytou, C., and Raff, M. C. (1997). Effects of thyroid hormone on embryonic oligodendrocyte precursor cell development in vivo and in vitro. Mol. Cell. Neurosci. 9: 420-432.

Araque, A., Parpura, V., Sanzgiri, R. P., and Haydon, P. G. (1999). Tripartite synapses: Glia, the unacknowledged partner. Trends Neurosci. 22: 208-215.

Armstrong, R. C., Kim, J. G., and Hudson, L. D. (1995). Expression of myelin transcription factor I (MyTI), a "Zinc-Finger" DNA-binding protein, in developing oligodendrocytes. Glia 14: 303-321.

Artavanis-Tsakonas, S., Rand, M.-D., and Lake, R.-J. (1999). Notch signaling: Cell fate control and signal integration in development. Science 284: 770-776.

Awatramani, R., Sherer, S., Grinspan, J., Collarini, E., Skoff, R., O'Hagan, D., Garbern, J., and Kamholz, J. (1997). Evidence that the homeodomain protein Gtx is involved in the regulation of oligodendrocyte myelination. J. Neurosci. 17: 6657-6668.

Bansal, R., Kumar, M., Murray, K., Morrison, R. S., and Pfeiffer, S. E. (1996). Regulation of FGF receptors in the oligodendrocyte lineage. Mol. Cell. Neurosci. 7: 263-275.

Barres, B. A., Hart, I. K., Coles, H. S., Burne, J. F., Voyvodic, J. T., Richardson, W. D., and Raff, M. C. (1992). Cell death and control of cell survival in the oligodendrocyte lineage. Cell 70:31-46.

Barres, B. A., and Raff, M. C. (1993). Proliferation of oligodendrocyte precursors cells depends on electrical activity in axons. Nature 361: 258-260.

Barres, B. A., Lazar, M. A., and Raff, M. C. (1994). A novel role for thyroid hormone, glucocorticoids and retinoic acid in timing oligodendrocyte development. Development 120: 1097-1108.

Barres, B. A. (1999). A new role for Glia: Generation of neurons! Cell 97: 667-670.

Belachew, S., Malgrange, B., Rigo, J. M., Rogister, B., Coucke, P., Mazy-Servais, C., and Moonen, G. (1998a). Developmental regulation of neuroligand-induced responses in cultured oligodendroglia. Neuroreport 9: 973-980.
Belachew, S., Rogister, B., Rigo, J. M., Malgrange, B., Mazy-Servais, C., Xhauflaire, G., Coucke, P., and Moonen, G. (1998b). Cultured oligodendrocyte progenitors derived from cerebral cortex express a glycine receptor which is pharmacologically distinct from the neuronal isoform. Eur. J. Neurosci. 10: 3556-3564.

Bellefroid, E.-J., Bourguignon, C., Hollemann, T., Ma, Q., Anderson, D.-J., Kintner, C., and Pieler, T. (1996). X-MyT1, a xenopus C2HCtype zinc finger protein with a regulatory function in neuronal differentiation. Cell 87: 1191-1202.

Ben-Hur, T., Rogister, B., Murray, K., Rougon, G., and Dubois-Dalcq, M. (1998). Growth and fate of PSA-NCAM+ precursors of the postnatal brain. J. Neurosci. 18: 5777-5788.

Bernardoni, R., Miller, A. A., and Giangrande, A. (1998). Glial differentiation does not require a neural ground state. Development 125: 3189-200.

Birling, M. C., and Price, J. (1998). A study of the potential of the embryonic rat telencephalon to generate oligodendrocytes. Dev. Biol. 193: 110-113.

Blaschuk, K. L., and ffrench-Constant, C. (1998). Developmental neurobiology: Notch is top in the developing brain. Curr. Biol. 8: R334-337.

Bogler, O., Wren, D., Barnett, S. C., Land, H., and Noble, M. (1990). Cooperation between two growth factors promotes extended selfrenewal and inhibits differentiation of oligodendrocyte-type-2 astrocyte (O-2A) progenitor cells. Proc. Natl. Acad. Sci. USA 87: 6368-6372.

Briscoe, J., Sussel, L., Serup, P., Hartigan-O'Connor, D., Jessel, T. M., Rubenstein, J. L. R., and Ericson, J. (1999). Homeobox gene Nkx 2.2 and specification of neuronal identity by graded Sonic hedgehog signalling. Nature 398: 622-627.

Brüstle, O., Choudary, K., Karram, K., Huttner, A., Murray, K., Dubois-Dalcq, M., and McKay, R. D. (1998). Chimeric brains generated by intraventricular transplantation of fetal human brain cells into embryonic rats. Nat. Biotechnol. 16: 1040-1044.

Brüstle, O., and Dubois-Dalcq, M. (1999). Stem cells and their gliogenic potential. In Glial Cell Development (K. R. Jessen and W. D. Richardson, Eds.) Oxford Univ. Press. In press.

Burrows, R. C., Wancio, D., Levitt, P., and Lillien, L. (1997). Response diversity and the timing of progenitor cell maturation are regulated by developmental changes in EGFR expression in cortex. Neuron 19: 251-267.

Buttery, P. C., and ffrench-Constant, C. Laminin-2/integrin interactions enhance myelin membrane formation by oligodendrocytes. Mol. Cell. Neurosci., 14:133-216.

Calver, A. R., Hall, A. C., Yu, W. P., Walsh, F. S., Heath, J. K., Betsholtz, C., and Richardson, W. D. (1998). Oligodendrocyte population dynamics and the role of PDGF in vivo. Neuron 20: 869-882.

Canoll, P. D., Musacchio, J. M., Hardy, R., Reynolds, R., Marchionni, M. A., and Salzer, J. L. (1996). GGF/neuregulin is a neuronal signal that promotes the proliferation and survival and inhibits the differentiation of oligodendrocyte progenitors. Neuron 17: 229-243.

Carre, J. L., Demerens, C., Rodriguez-Pena, A., Floch, H. H., Vincendon, G., and Sarlieve, L. L. (1998). Thyroid hormone receptor isoforms are sequentially expressed in oligodendrocyte lineage cells during rat cerebral development. J. Neurosci. Res. 54: 584-594.

Casaccia-Bonnefil, P., Tikoo, R., Kiyokawa, H., Friedrich, V. Jr., Chao, M. V., and Koff, A. (1997). Oligodendrocyte precursor differentiation is perturbed in the absence of the cyclin-dependent kinase inhibitor p27Kip1. Genes Dev. 11: 2335-2346.

Chandross, K. J., Cohen, R. I., Paras, P. J., Gravel, M., Braun, P. E., and Hudson, L. D. (1999). Identification and characterization of early Glial progenitors using a transgenic selection strategy. J. Neurosci. 19: $759-774$.

Cheng, C. M., Joncas, G., Reinhardt, R. R., Farrer, R., Quarles, R., Janssen, J., McDonald, M. P., Crawley, J. N., Powell-Braxton, L., and 
Rogister, Ben-Hur, and Dubois-Dalcq

Bondy, C. A. (1998). Biochemical and morphometric analyses show that myelination in the insulin-like growth factor 1 null brain is proportionate to its neuronal composition. J. Neurosci. 18: 5673-5681.

Chenn, A., and McConnell, S. K. (1995). Cleavage orientation and the asymmetric inheritance of Notch1 immunoreactivity in mammalian neurogenesis. Cell 82: 631-641.

Chew, L. J., Fleck, M. W., Wright, P., Scherer, S. E., Mayer, M. L., and Gallo, V. (1997). Growth factor-induced transcription of GluR1 increases functional AMPA receptor density in glial progenitor cells. J. Neurosci. 17: 227-240.

Ciccolini, F., and Svendsen, C. N. (1998). Fibroblast growth factor 2 (FGF2) promotes acquisition of epidermal growth factor (EGF) responsiveness in mouse striatal precursor cells: Identification of neural precursors responding to both EGF and FGF2. J. Neurosci. 18: 7869-7880.

Colman, D. R., Doyle, J. P., D’Urso, D., Kitagawa, K., Pedraza, L., Yoshida, M., and Fannon, A. M. (1996). Speculations on myelin sheath evolution. In Glial Cell Development (K. R. Jessen and W. D. Richardson, Eds.), pp. 85-101. Bios Scientific, Oxford, UK.

Davis, A. A., and Temple, S. (1994). A self-renewing multipotential stem cell in embryonic rat cerebral cortex. Nature 372: 263-266.

De Bellard, M. E., and Filbin, M. T. (1999). Myelin-Associated glycoprotein, MAG, selectively binds several neuronal proteins. J. Neurosci. Res. 56: 213-218.

Demerens, C., Stankoff, B., Logak, M., Anglade, P., Allinquant, B., Couraud, F., Zalc, B., and Lubetzki, C. (1996). Induction of myelination in the central nervous system by electrical activity. Proc. Natl. Acad. Sci. USA 93: 9887-9892.

Dodd, J., Jessell, T. M., and Placzek, M. (1998). The when and where of floor plate induction. Science 282: 1654-1657.

Doetsch, F., Caillé, I., Lim, D. A., Garcia-Verdugo, J. M., and AlvarezBullya, A. (1999). Subventricular Zone astrocytes are neural stem cells in the adult mammalian brain. Cell 97: 703-716.

Dubois-Dalcq, M. (1987). Characterization of a slowly proliferative cell along the oligodendrocyte differentiation pathway. EMBO J. 6: 25872595.

Dubois-Dalcq, M., and Armstrong, R. (1990). The cellular and molecular events of central nervous system remyelination. Bioessays 12: 569-576.

Dubois-Dalcq, M., and Armstrong, R. (1992). The oligodendrocyte lineage during myelination and remyelination. In Myelin: Biology and Chemistry (R. E. Martenson, Ed.), Chapt. I, pp. 81-122. Telford, Caldwell, NJ.

Duprée, J. L., Coetzee, T., Blight, A., Suzuki, K., and Popko, B. (1998). Myelin galactolipids are essential for proper node of Ranvier formation in the CNS. J. Neurosci. 18: 1642-1649.

Durand, B., Gao, F. B., and Raff, M. C. (1997). Accumulation of the cyclin-dependent kinase inhibitor p27/Kip1 and the timing of oligodendrocyte differentiation. EMBO J. 16: 306-317.

Durand, B., Fero, M. L., Roberts, J. M., and Raff, M. C. (1998). p27Kip1 alters the response of cells to mitogen and is part of a cell-intrinsic timer that arrests the cell cycle and initiates differentiation. Curr. Biol. 8: 431-440.

Edlund, T., and Jessell, T. M. (1999). Progression from extrinsic to intrinsic signaling in cell fate specification: A view from the nervous system. Cell 96: 211-224.

Filbin, M. T. (1996). The Muddle with MAG. Mol. Cell. Neurosci. 8: 84-92.

Fruttiger, M., Karlsson, L., Hall, A. C., Abramson, A., Calver, A. R., Bostrom, H., Willets, K., Bertold, C. H., Heath, J. K., Betsholtz, C., and Richardson, W. D. (1999). Defective oligodendrocyte development and severe hypomyelination in PDGF-A knockout mice. Development 126: 457-467.

Gallo, V., Zhou, J. M., McBain, C. J., Wright, P., Knutson, P. L., and Armstrong, R. C. (1996). Oligodendrocyte progenitor cell prolifera- tion and lineage progression are regulated by glutamate receptormediated K+ channel block. J. Neurosci. 16: 2659-2670.

Gauthier, K., Chassande, O., Plateroti, M., Roux, J. P., Legrand, C., Pain, B., Rouset, B., Weiss, R., Trouillas, J., and Samarut, J. (1999). Different functions for the thyroid hormone receptors TRalpha and TRbeta in the control of thyroid hormone production and post-natal development. EMBO J. 18: 623-631.

Ghiani, C. A., Eisen, A. M., Yuan, X., DePinho, R. A., McBain, C. J., and Gallo, V. (1999a). Neurotransmitter receptor activation triggers p27(Kip1) and p21(CIP1) accumulation and G1 cell cycle arrest in oligodendrocyte progenitors. Development 126: 1077-1090.

Ghiani, C. A., Yuan, X., Eisen, A. M., Knutson, P. L., DePinho, R. A., McBain, C. J., and Gallo, V. (1999b). Voltage-activated K+ channels and membrane depolarization regulate accumulation of the cyclindependent kinase inhibitors p27kip1 and p21cip1 in glial progenitor cells. J. Neurosci. 19: 5380-5392.

Giordano, S., Sherman, L., Lyman, W., and Morrison, R. (1992). Multiple molecular weight forms of basic fibroblast growth factor are developmentally regulated in the central nervous system. Dev. Biol. 152: 293-303.

Granneman, J., Skoff, R., and Yang, X. (1998). Member of the peroxisome proliferator-activated receptor family of transcription factors is differentially expressed by oligodendrocytes. J. Neurosci. Res. 51: 563-573.

Griffiths, I., Klugmann, M., Anderson, T., Yool, D., Thomson, C., Schwab, M. H., Schneider, A., Zimmermann, F., McCulloch, M., Nadon, N., and Nave, K. A. (1998). Axonal swelling and degeneration in mice lacking the major proteolipid of myelin. Science 280: 1610-1613.

Gross, R. E., Mehler, M. F., Mabie, P. C., Zang, Z., Santschi, L., and Kessler, J. A. (1996). Bone morphogenetic proteins promote astroglial lineage commitment by mammalian subventricular zone progenitor cells. Neuron 17: 595-606.

Hajihosseini, M., Tham, T. N., and Dubois-Dalcq, M. (1996). Origin of oligodendrocytes within the human spinal cord. J. Neurosci. 16: 79817994.

Hardy, R. J., and Friedrich, V. L. (1996). Oligodendrocyte progenitors are generated throughout the embryonic mouse brain but differentiate in restricted foci. Development 122: 2059-2069.

Hardy, R. J. (1998). QKI expression is regulated during neuron-glial cell fate decisions. J. Neurosci. Res. 54: 46-57.

Hu, H., Tomasiewicz, H., Magnuson, T., and Rutishauser, U. (1996). The role of polysialic acid in migration of olfactory bulb interneuron precursors in the subventricular zone. Neuron 16: 735-743.

Hudson, L. D., Ko, N., and Kim, J. G. (1996). Control of myelin gene expression. In Glial Cell Development (K. R. Jessen and W. D. Richardson, Eds.), pp. 118-139. Bios Scientific, Oxford, UK.

Hudson, L. D. (1999). Control of gene expression by oligodendrocytes. In Glial Cell Development (K. R. Jessen and W. D. Richardson, Eds.) Oxford Univ. Press. In press.

Huttner, W. B., and Brand, M. (1997). Asymmetric division and polarity of neuroepithelial cells. Curr. Opin. Neurobiol. 7: 29-39.

Jensen, N. A., Pedersen, K. M., Celis, J. E., and West, M. J. (1998). Neurological disturbances, premature lethality, and central myelination deficiency in transgenic mice overexpressing the homeo domain transcription factor Oct-6. J. Clin. Invest. 101: 1292-1299.

Jessen, K. R., and Mirsky, R. (1998). Origin and early development of Schwann cells. Microsc. Res. Tech. 41: 393-402.

Johansson, C. B., Momma, S., Clarke, D. L., Risling, M., Lendahl, U., and Frisen, J. (1999). Identification of a neural stem cell in the adult mammalian central nervous system. Cell 96: 25-34.

Johe, K. K., Hazel, T. G., Müller, T., Dugich-Djordjevic, M. M., and McKay, R. D. G. (1996). Single factors direct the differentiation of 
stem cells from the fetal and adult central nervous system. Genes Dev. 10: 3129-3140.

Jones, B. W., Fetter, R. D., Tear, G., Goodman, C. S. (1995). Glial cells missing: A genetic switch that controls glial versus neuronal fate. Cell 82: 1013-1023.

Kaplan, M. R., Meyer-Franke, A., Lambert, S., Bennet, V., Duncan, I. D., Levinson, S. R., and Barres, B. A. (1997). Induction of sodium channel clustering by oligodendrocytes. Nature 386: 724-728.

Keirstead, H. S., Ben-Hur, T., Rogister, B., O'Leary, Dubois-Dalcq, M., and Blakemore, W. F. (1999). PSA-NCAM positive CNS precursors generate both oligodendrocytes and Schwann cells to remyelinate the CNS following transplantation. J. Neurosci. 19:7529-7536.

Kiernan, B. W., Götz, B., Faissner, A., and ffrench-Constant, C. (1996). Tenascin- $C$ inhibits oligodendrocyte precursor cell migration by both adhesion-dependent and adhesion-independent mechanisms. Mol. Cell. Neurosci. 7: 322-335.

Kim, J. G., Armstrong, R. C., Agoston, D., Robinsky, A., Wiese, C., Nagle, J., and Hudson, L. D. (1997). Myelin transcription (MytI) of the oligodendrocyte lineage, along with a closely related CCHC zinc finger, is expressed in developing neurons in the mammalian central nervous system." J. Neurosci. Res. 50: 272-290.

Kiss, J. Z., and Rougon, G. (1997). Cell biology of polysialic acid. Curr. Opin. Neurobiol. 7: 640-646.

Knutson, P., Ghiani, C. A., Zhou, J. M., Gallo, V., and McBain, C. J. (1997). K+ channel expression and cell proliferation are regulated by intracellular sodium and membrane depolarization in oligodendrocyte progenitor cells. J. Neurosci. 17: 1669-1682.

Krämer, E. V., Klein, C., Koch, I., Boytinck, and Trotter, J. Compartmentation of Fyn kinase with glycosylphosphatidylinositol-anchored molecules in oligodendrocytes facilitates activation during myelination. J. Biol. Chemistry. 274, in press.

Kulhbrodt, K., Herbarth, B., Sock, E., Hermans-Borgmeyer, I., and Wegner, M. (1998). Cooperative function of POU proteins ans SOX proteins in glial cells. J. Biol. Chem. 273: 16050-16057.

Levison, S. W., and Goldman, J. E. (1993). Both oligodendrocytes and astrocytes develop from progenitors in the subventricular zone of postnatal rat forebrain. Neuron 10: 201-212.

Li, C., Trapp, B., Ludwin, S., Peterson, A., and Roder, J. (1998). Myelin associated glycoprotein modulates glia-axon contact in vivo. $J$. Neurosci. Res. 51: 210-217.

Lillien, L. (1998). Neural progenitors and stem cells: Mechanisms of progenitor heterogeneity. Curr. Opin. Neurobiol. 8: 37-44.

Marigo, V., and Tabin, C. J. (1996). Regulation of patched by sonic hedgehog in the developing neural tube. Proc. Natl. Acad. Sci. USA 93: 9346-9351.

Marmur, R., Kessler, J. A., Zhu, G., Gokhan, S., and Mehler, M. F. (1998). Differentiation of oligodendroglial progenitors derived from cortical multipotent cells requires extrinsic signals including activation of gp130/LIFb receptors. J. Neurosci. 18: 9800-9811.

Martinez, S., and Cobos, I. (1998). Regional and cellular specification in the prosencephalic anlage of the neural plate. Eur. J. Neurosci. 10 (Supplement): 323.

Martini, R., and Schachner, M. (1997). Molecular bases of myelin formation as revealed by investigations on mice deficient in glial cell surface molecules. Glia 19: 298-310.

McKay, R. (1997). Stem cells in the central nervous system. Science 276: 66-71.

McKinnon, R. D., Matsui, T., Dubois-Dalcq, M., and Aaronson, S. A. (1990). FGF modulates the PDGF-driven pathway of oligodendrocyte development. Neuron 5: 603-614.
McMorris, F. A., and McKinnon, R. D. (1996). Regulation of oligodendrocyte development and CNS myelination by growth factors: Prospects for therapy of demyelinating disease. Brain Pathol. 6: 313-329.

Meyer, D., Yamaai, T., Garratt, A., Riethmacher-Sonnenberg, E., Kane, D., Theill, L. E., and Birchmeier, C. (1998). Isoform-specific expression and function of neuregulin. Development 124: 3575-3586.

Miller, R. H. (1996). Oligodendrocyte origins. Trends Neurosci. 19: 92-96.

Milner, R., Edwards, G., Streuli, C., and ffrench-Constant, C. (1996). A role in migration for the alpha $\mathrm{v}$ beta 1 integrin expressed on oligodendrocyte precursors. J. Neurosci. 16: 7240-7252.

Milner, R., Frost, E., Nishimura, S., Delcommenne, M., Streuli, C., Pytela, R., and ffrench-Constant, C. (1997). Expression of alpha v beta 3 and alpha v beta 8 integrins during oligodendrocyte precursors differentiation in the presence and absence of axons. Glia 21: 350-360.

Murphy, P., Topilko, P., Schneider-Maunoury, S., Seitanidou, T., BaronVan Evercooren, A., and Charnay, P. (1996). The regulation of Krox-20 expression reveals important steps in the control of peripheral glial cell development. Development 122: 2847-2857.

Murray, K., and Dubois-Dalcq, M. (1997). Emergence of oligodendrocytes from human neural spheres. J. Neurosci. Res. 50: 146-156.

Nait-Oumesmar, B., and Lazzarini, R. A. (1999). Molecular organization and expression pattern of the murine Gcm1 gene. Abstract presented at the 6th ENBDD Meeting on Developmental defect of myelin formation and undetermined leukodystrophies in Praglia, Italy (May 27-29, 1999).

Nishiyama, A., Lin, X. H., Giese, N., Heldin, C. H., and Stallcup, W. B. (1996). Co-localization of NG2 proteoglycan and PDGF alphareceptor on $\mathrm{O} 2 \mathrm{~A}$ progenitor cells in the developing rat brain. $J$. Neurosci. Res. 43: 299-314.

Noble, M., Wren, D., and Wolswijk, G. (1992). The O-2A (adult) progenitor cell: A glial stem cell of the adult central nervous system. Semin. Cell Biol. 3: 413-422.

Ono, K., Yasui, Y., Rutishauser, U., and Miller, R. H. (1997). Focal ventricular origin and migration of oligodendrocyte precursors into optic nerve. Neuron 19: 283-292.

Orentas, D.-M., Hayes, J.-E., Dyer, K.-L., and Miller, R.-H. (1999). Sonic hedgehog signaling is required during the appearance of spinal cord oligodendrocyte precursors. Development 126: 2419-2429.

Pende, M., Fisher, T. L., Simpson, P. B., Russell, J. T., Blenis, J., and Gallo, V. (1997). Neurotransmitter- and growth factor-induced cAMP response element binding protein phosphorylation in glial cell progenitors: Role of calcium ions, protein kinase $\mathrm{C}$, and mitogen-activated protein kinase/ ribosomal S6 kinase pathway. J. Neurosci. 17: 1291-1301.

Perez-Juste, and Aranda, A. (1999). The cyclin-dependent kinase inhibitor p27 (Kip1) is involved in thyroid hormone-mediated neuronal differentiation. J. Biol. Chem. 274: 5026-5031.

Pesheva, P., Gloor, S., Schachner, M., and Probstmeier, R. (1997). Tenascin- $\mathrm{R}$ is an intrinsic autocrine factor for oligodendrocyte differentiation and promotes cell adhesion by a sulfatide-mediated mechanism. J. Neurosci. 17: 4642-4651.

Pfeiffer, S. E., Warrington, A. E., and Bansal, R. (1993). The oligodendrocyte and its many cellular processes. Trends Cell Biol. 3: 191-197.

Powell, S. K., Williams, C. C., Nomizu, M., Yamada, Y., and Kleinman, H. K. (1998). Lamini-like proteins are differentially regulated during cerebellar development and stimulate granule cell neurite outgrowth in vitro. J. Neurosci. Res. 54: 233-247.

Qian, X., Davis, A. A., Goderie, S. K., and Temple, S. (1997). FGF2 concentration regulates the generation of neurons and glia from multipotent cortical stem cells. Neuron 18: 81-93.

Raff, M. C. (1989). Glial cell diversification in the rat optic nerve. Science 243: 1450-1455. 
Raff, M. C., Barres, B. A., Burne, J. F., Coles, H. S., Ishizaki, Y., and Jacobson, M. D. (1993). Programmed cell death and the control of cell survival: Lessons from the nervous system. Science 262: 695-700.

Rajan, P., and McKay, R. D. (1998). Multiple routes to astrocytic differentiation in the CNS. J. Neurosci. 18: 3620-3629.

Rao, M. S., and Mayer-Proschel, M. (1997). Glial-restricted precursors are derived from multipotent neuroepithelial stem cells. Dev. Biol. 188: 48-63.

Reddy, U. R., and Pleasure, D. (1992). Expression of platelet-derived growth factor (PDGF) and PDGF receptor genes in the developing rat brain. J. Neurosci. Res. 31: 670-677.

Richardson, W. D., Pringle, N. P., Yu, W. P., and Hall, A. C. (1997). Origins of spinal cord oligodendrocytes: Possible developmental and evolutionary relationships with motor neurons. Dev. Neurosci. 19: 58-68.

Robinson, S., Tani, M., Strieter, R. M., Ransohoff, R. M., and Miller, R. H. (1998). The chemokine growth-regulated oncogene-alpha promotes spinal cord oligodendrocyte precursor proliferation. $J$. Neurosci. 18: 10457-10463.

Rougon, G., Olive, S., and Figarella-Branger, D. (1993). Is PSA-NCAM a marker for cell plasticity? In Polysialic Acid: from microbes to man. (J. Roth, U. Rutishauer, and F. A. Troy, Eds.), pp. 323-333. BirkhaÜser Verlag, Basel, Switzerland.

Rubinstein, J. L., Shimamura, K., Martinez, S., and Puelles, L. (1998). Regionalization of the prosencephalic neural plate. Annu. Rev. Neurosci. 21: 445-477.

Sakakibara, S., and Okano, H. (1997). Expression of neural RNAbinding proteins in the postnatal CNS: implications of their roles in neuronal and glial cell development. J. Neurosci. 17: 8300-8312.

Sasahara, A., Kott, J. N., Sasahara, M., Raines, E. W., Ross, R., and Westrum, L. E. (1992). Platelet-derived growth factor B-chain-like immunoreactivity in the developing and adult rat brain. Brain Res. Dev. Brain Res. 68: 41-53.

Scherer, S. S., Deschenes, S. M., Xu, Y. T., Grinspan, J. B., Fishbeck, K. H., and Paul, D. L. (1995). connexin32 is a myelin-related protein in the PNS and CNS. J. Neurosci. 15: 8281-8294.

Schreiber, J., Enderich, J., Sock, E., Schmidt, C., Richter-Landsberg, C., and Wegner, M. (1997). Redundancy of class III POU proteins in the oligodendrocyte lineage. J. Biol. Chem. 272: 32286-32293.

Shi, J., Marinovich, A., and Barres, B. A. (1998). Purification and characterization of adult oligodendrocyte precursor cells from the rat optic nerve. J. Neurosci. 18: 4627-4636.

Simpson, P. B., and Armstrong, R. C. (1999). Intracellular signals and cytoskeletal elements involved in oligodendrocyte progenitor migration. Glia 26: 22-35.

Sock, E., Leger, H., Kuhlbrodt, K., Schreiber, J., Enderich, J., RichterLandsberg, C., and Wegner, M. (1997). Expression of Krox proteins during differentiation of the O-2A progenitor cell line CG-4. J. Neurochem. 68: 1911-1919.

Spassky, N., Goujet-Zalc, C., Parmantier, E., Olivier, C., Martinez, S., Ivanova, A., Ikenaka, K., Macklin, W., Cerruti, I., Zalc, B., and Thomas, J. L. (1998). Multiple restricted oigin of oligodendrocytes. J. Neurosci. 18: 8331-8343.

Stemple, D. L., and Anderson, D. J. (1992). Isolation of a stem cell for neurons and glia from the mammalian neural crest. Cell 71: 973-985.

Stoffel, W., and Bosio, A. (1997). Myelin glycolipids and their functions. Curr. Opin. Neurobiol. 7: 654-661.

Sun, T., Pringle, N. P., Hardy, A. P., Richardson, W. D., and Smith, H. K. (1998). Pax6 influences the time and site of origin of glial precursors in the ventral neural tube. Mol. Cell. Neurosci. 12: 228-239.
Timsit, S., Martinez, S., Allinquant, B., Peyron, F., Puelles, L., and Zalc, B. (1995). Oligodendrocytes originate in a restricted zone of the embryonic ventral neural tube defined by DM-20 mRNA expression. J. Neurosci. 15: 1012-1024.

Tosic, M., Torch, S., Comte, V., Dolivo, M., Honegger, P., and Matthieu, J. M. (1992). Triiodothyronine has diverse and multiple stimulating effects on expression of the major myelin protein genes. J. Neurochem. 59: 1770-1777.

Trapp, B. D., Peterson, J., Ransohoff, R. M., Rudick, R., Mörk, S., and Bö, L. (1998). Axonal transection in the lesions of multiple sclerosis. New Engl. J. Med. 338: 278-285.

Vartanian, T., Goodearl, A., Viehöver, A., and Fischbach, G. (1997). Axonal neuregulin signals cells of the oligodendrocyte lineage through activation of HER4 and Schwann cells through HER2 and HER3. J. Cell Biol. 137: 211-220.

Vartanian, T., Fischbach, G., and Miller, R. H. (1999). Failure of spinal cord oligodendrocyte development in mice lacking neuregulin. Proc. Natl. Acad. Sci. USA 96: 731-735.

Wallace, V. A. and Raff, M. C. (1999). A role for sonic hedgehog in axon-to-astrocyte signalling in the rodent optic nerve. Development 126: 2901-2909.

Walters, S. N., and Morell, P. (1981). Effects of altered thyroid states on myelinogenesis. J. Neurochem. 36: 1792-1801.

Wang, S., Sdrulla, A. D., diSibio, G., Bush, G., Nofziger, D., Hicks, C., Weinmaster, G., and Barres, B. A. (1998a). Notch receptor activation inhibits oligodendrocyte differentiation. Neuron 21: 63-75.

Wang, S., Wu, H., Jiang, J., Delohery, T. M., Isdell, F., and Goldman, S. A. (1998b). Isolation of neuronal precursors by sorting embryonic forebrain transfected with GFP regulated by the T alpha 1 tubulin promoter. Nature Biotechnol. 16: 196-201.

Wechsler-Reya, R.-J., and Scott, M.-P. (1999). Control of neuronal precursor proliferation in the cerebellum by sonic hedgehog. Neuron 22: 103-114.

Weiss, S., Reynolds, B. A., Vescovi, A. L., Morshead, C., Craig, C. G., and van der Kooy, D. (1996). Is there a neural stem cell in the mammalian forebrain? Trends Neurosci. 19: 387-393.

Wichterle, H., Garcia-Verdugo, J. M., and Alvarez-Buylla, A. (1997). Direct evidence for homotypic, glia-independent neuronal migration. Neuron 18: 779-791.

Williams, B. P., Park, J. K., Alberta, J. A., Muhlebach, S. G., Hwang, G. Y., Roberts, T. M., and Stiles, C. D. (1997). A PDGF-regulated immediate early gene response initiates neuronal differentiation in ventricular zone progenitor cells. Neuron 18: 553-562.

Williams, B. P., and Price, J. (1995). Evidence for multiple precursor cell types in the embryonic rat cerebral cortex. Neuron 14: 1181-1188.

Yandava, B. D., Billinghurst, L. L., and Snyder, E. Y. (1999). Global cell replacement is feasible via neural stem cell transplantation: Evidence from the dysmyelinated shiverer mouse brain. Proc. Natl. Acad. Sci. USA 96: 7029-7034.

Yin, X., Crawford, T. O., Griffin, J. W., Tu, Ph., Lee, V. M., Li, C., Roder, J., and Trapp, B. D. (1998). Myelin-associated glycoprotein is a myelin signal that modulates the caliber of myelinated axons. $J$. Neurosci. 18: 1953-1962.

Yuan, X., Eisen, A. M., McBain, C. J., and Gallo, V. (1998). A role for glutamate and its receptors in the regulation of oligodendrocyte development in cerebral tissue slices. Development 125: 2901-2914.

Zhang, S. C., Ge, B., and Duncan, I. D. (1999). Adult brain retains the potential to generate oligodendroglial progenitors with extensive myelination capacity. Proc. Natl. Acad. Sci. USA 96: 4089-4094. 